\title{
Trajectories of the early-modern kingdoms in eastern Indonesia: Comparative perspectives
}

\author{
Hans Hägerdal
}

\section{Introduction}

The king grew increasingly powerful. His courage indeed resembled that of a lion. He wisely attracted the hearts of the people. The king was a brave man who was sakti and superior in warfare. In fact King Waturenggong was like the god Vishnu, at times having four arms. The arms held the cakra, the club, si Nandaka, and si Pañcajania. How should this be understood? The keris Ki Lobar and Titinggi were like the club and cakra of the king. Ki Tandalanglang and Ki Bangawan Canggu were like Sangka Pañcajania and the keris si Nandaka; all were the weapons of the god Vishnu which were very successful in defeating ferocious enemies. The permanent force of the king was called Dulang Mangap and were 1,600 strong. Like Kalantaka it was led by Kriyan Patih Ularan who was like Kalamretiu. It was dispatched to crush Dalem Juru [king of Blambangan] since Dalem Juru did not agree to pass over his daughter Ni Bas [...]

All the lands submitted, no-one was the equal to the king in terms of bravery. They were all ruled by him: Nusa Penida, Sasak, Sumbawa, and especially Bali. Blambangan until Puger had also been subjugated, all was lorded by him. Only Pasuruan and Mataram were not yet [subjugated]. These lands were the enemies (Warna 1986: 78, 84).

Thus did a Balinese chronicler recall the deeds of a sixteenth-century ruler who supposedly built up a mini-empire that stretched from East Java to Sumbawa. Although his warlike exploits are insufficiently documented, European sources from the late sixteenth century do confirm the existence of a Balinese kingdom of some consequence. What strikes the reader of the chronicle - which was authored sometime after the last mentioned events in the $1680 \mathrm{~s}$ - is the references to Indian models. The sacred daggers of the king are likened to the attributes held by Vishnu. The king himself is portrayed as a world-ruler, a cakravartin, with parallels to the contemporary rulers of the Southeast Asian mainland, men such as Bayinnaung, Naresuan, Phothisarat and Ang Chan. While, for example, the Thai kingdom of Ayudhya may have been 40-50 times larger than Bali, the royal imagery of the little island realm reminds us that there were historical processes going on in the insular world east of Java with interesting parallels to the larger Southeast Asian kingdoms.

While the larger pre-modern state structures of Mainland Southeast Asia and Java-Sumatra have long received much scholarly attention by historians and archaeologists, what lay east of Java was uncharted territory until rather recently. These areas have been interesting fields of study for anthropologists, linguists, and students of material culture. Analyses of eastern Indonesian societies have often departed from structural models observed through modern ethnographic data, such as power dualism, quadripartition, systems of marital exchange, and so on. The small scale of traditional polities in the region, and the lack of indigenous writings 
in most of them, have not been conducive to the application of historical methods used to study statecraft in Ayudhya, Đai Viêt, Aceh, Mataram, etc. (Hägerdal 2015).

Since about the 1970s, however, much has happened. In recent decades the anatomies of the polities of Bali, the Spice Islands, Sumbawa and Timor have had their fair share of academic scrutiny. The Hindu micro-states of Bali, which flourished up to the early twentieth century, have been an attractive area of research due to the availability of indigenous texts and the enticing anthropological perspectives, where the much-debated thesis of Clifford Geertz about the negara state has engendered many new queries (Geertz 1980). How were the small indianized kingdoms on the island organized, and what were the bases of their prestige and resources? Furthermore Henri Chambert-Loir has studies indigenous texts from Bima on Sumbawa which reveal a rather accomplished state structure (Chambert-Loir 1993; Chambert-Loir 2010). The spice sultanates of northern Maluku have likewise received some attention by historians such as Leonard Andaya and Muridan Widjojo: how could small island polities build up comprehensive power networks, how were they helped by Islam and "traditional" beliefs, and how could they exist concurrently with monitoring European powers? (Andaya 1993; Widjojo 2009). Finally, the fragmented and highly localized polities of Timor and adjacent islands have been studied in some detail, mainly by anthropologists such as Herman Schulte Nordholt (1971) and James Fox (1977). Much insight has been gained in the intricate structure of the realms, which structurally lie somewhere on a continuum between kingdoms and chiefdoms.

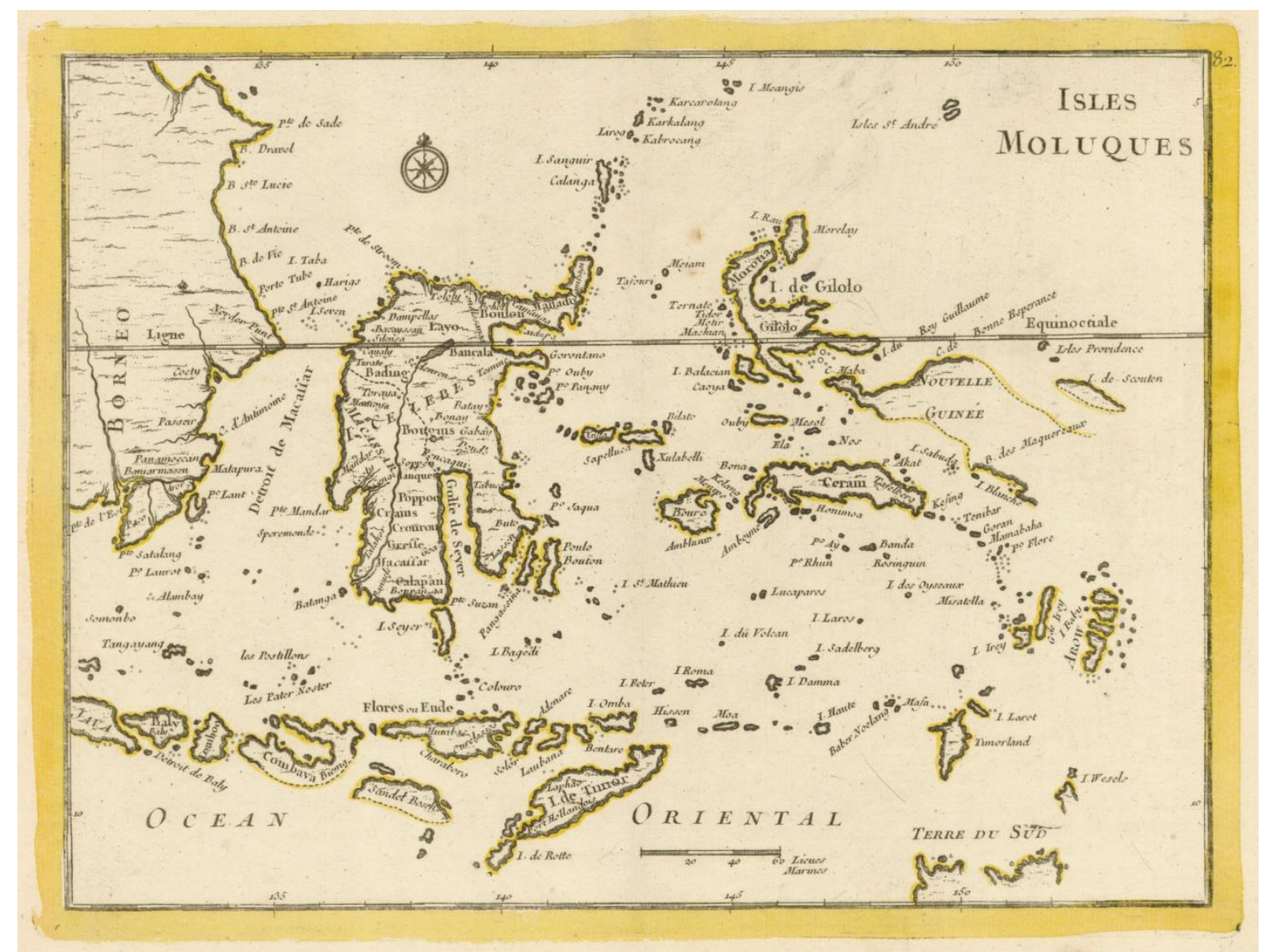

A map of eastern Indonesia from 1748. From G.-L. le Rouge, Atlas nouveau portatif (Paris, 1748). 
While these studies have greatly increased our understanding of the historical societies of eastern Indonesia, the situation of the source materials makes it hard to reach back before the arrival of the Europeans in the sixteenth century (with the partial exception of Bali, where we possess epigraphical records back to the ninth century). Also, the picture that emerges remains to be compared with the larger kingdoms on the mainland and the central-western parts of the Archipelago which arose from about the fourteenth-fifteenth century, what Victor Lieberman has termed the post-charter states (Lieberman 2003-2009). There has been a lively discussion about Southeast Asian statecraft over the years where many scholars apply a "cosmic" model: while European states are characterised by fixed borders and bureaucratic institutions, Southeast Asian polities are more dispersed, somewhat like components of a galaxy. An exemplary centre binds satellites to its power more or less efficiently depending on its fluid capabilities. Not even smaller polities - the normal type in the pre-modern history of much of Southeast Asia - are characterized by any administrative solidity. Stanley Tambiah (2013: 528) speaks of administrative involution where the hierarchy of power and merit tends to fragment into a variety of competing administrative cells. In the well-known metaphor by the late Benedict Anderson, the state centre is like a lamp whose light (power, influence) diminishes with the distance (Anderson 2006: 21-3). One aspect of the dispersion is that regional and local lords tend to replicate the centre, thus emulating the institutions and ritual practices of the central lord as far as they can. Some scholars speak of a segmentary state where the constituents of a polity are structurally similar, so that their authority differs in extent rather than kind (Wellen 2014: 7-8). In these models the role of the ruler is paradoxical. As the central nave of a negara or polity, he is on one hand a passive maintainer of order rather than somebody who brings about change to achieve an ideal state of things. But on the other hand this passivity is punctuated by displays of warlike activity to defend or expand the realm (Tambiah 2013: 515-6).

The proponents of cosmic models draw their data from societies influenced by Indian culture, which is relevant for the mainland and Java but becomes problematic when we speak of eastern Indonesian societies. Bali is an obvious exception here, since several scholars have drawn parallels between this island and other indianized societies of South and Southeast Asia. For the majority of the hundreds of local polities that dotted the eastern Indonesian islands, it is debatable whether they should be properly be considered "kingdoms" at all. As noted by global historian Jared Diamond, the kingdom means a deepening and specialisation of hierarchical structures present in chiefdoms, and the borderline between the two is fluid (Diamond 1997: 278-9). It is however possible to make a rough classification of polities. In line with research by Henri Claessen and Jarich Oosten one may point out four basic criteria that a polity should meet to evolve into an early state in a meaningful sense: a sufficient number of people to constitute a complex society, control over an acknowledged area of land, institutions to harvest surplus (taxes, tributes), and an ideology that motivates unequal power relationships and institutions (Claessen and Oosten 1996: 4-16). While these criteria are fairly vague and flexible, they help us to single out some four geographical areas where early states emerged in the pre-colonial era, as will be seen below.

While Southeast Asia is a very late concept, Anthony Reid and several other historians have argued that it is justified to speak of it as a historical region with peculiar societal traits (Reid 1988-1993). Something similar has been argued with regard to eastern Indonesia, 
perhaps more by anthropologists than historians. In a recent thematic issue of the journal Archipel, l'Est insulindien was studied as a category from archaeological, linguistic, anthropological, and historical perspectives. ${ }^{1}$ The region is characterised by a stunning ecological diversity, which is matched by an ethno-linguistic one: three fourths of the 700 languages of Indonesia are spoken here, mostly by very small populations. While the eastern Indonesian cultures are far away from the large states and entrepôts of the mainland, Sumatra and Java, and may seem isolated to the outsider, this is not the whole truth. The ethnolinguistic groups mostly inhabit small or medium-sized islands, and the sea is omnipresent in ritual perceptions and connections to the outer world. The documented history of eastern Indonesia is filled with migrations, long-distance commerce, and cultural transfer (Rappoport and Guillaud 2015: 5-7). In the light of the important research on eastern Indonesian cultures that has accumulated in recent years, it is therefore worth the effort to study the evolution of pre-colonial statecraft in larger comparative perspectives. What I will do in this article is, first, to pinpoint some main characteristics of the polities of four areas of eastern Indonesia where polities of some consequence arose in the period from the fifteenth to the seventeenth centuries, more or less the age of commerce posited by Anthony Reid (1988). These are BaliLombok, Sumbawa, the Spice Sultanates, and the Timor area, which fulfil the criteria of statehood posited by .Claessen and Oosten to a degree. Secondly, I will compare these four areas with each other using a set of variables. And finally, I will tentatively ask whether some of the processes of integration found in the larger Southeast Asian states at the same time are somehow applicable to the smaller polities of eastern Indonesia. Thus the study asks to what extent state-building mechanisms in the larger kingdoms were paralleled by political structures in the smaller realms of the east, and how the latter were able to survive in some form until the twentieth century.

\section{Indianization and indigeneity: Bali and Lombok}

On the following pages some general trends among the historical societies of the four chosen regions of eastern Indonesia are presented. Given the article format, this can only be cursory, but it might give a rough idea about their preconditions in the early-modern period.

From an economic-historical point of view, Bali and at least sections of Lombok are parts of Central Indonesia, a region characterised by labour-intensive sawah culture and a relatively high population density. It is also known that Bali was politically subjugated by Javanese kingdoms for periods, and the same probably goes for Lombok. Balinese epigraphical records from the ninth to the fifteenth centuries prove the existence of an Indic type of kingship which issued grants to villages and religious institutions. After a period of Majapahit rule on Bali that began in 1343, a new indigenous line of kings was established on the island under very obscure circumstances. ${ }^{2}$ The ruler, his ministers, and grandees are

1 "L'Est insulindien", thematic issue in Archipel 902015.

2 Kempers 1991: 33-49. The traditional historiography is studied in detail in Berg (1927: 93-167). Due to lack of space I will be relatively brief on the quality of the sources for the study of eastern Indonesia in the fifteenth to seventeenth centuries. The lack of contemporary indigenous documents forces us to examine external (usually European) accounts and chronicles and traditions committed to paper at a much later date. While customs and institutions may have changed over time, it is likely that chronicles and other texts from the seventeenth century and later give an approximate idea of cultural processes in the preceding period. 
understood in later historiography to be Javanese nobles of Majapahit origins, but the lack of dated documents from the mid-fifteenth to the late sixteenth century makes it hard to judge all this.

What is certainly known is that the first Dutch visitors to Indonesia met the king of Bali in 1597 and provided descriptions of his entourage and court. The VOC (1602-1799) was never permanently established on Bali, and the reports written about the island are too cursory to enable us to say much about the dynamics of local kingship. What little there is implies a highly decentralized structure of the kingdom, with 33 local lords (termed "kings" by the Dutch) under the central ruler in Gelgel near the south coast whose title is given as Raja Dalem or Raja di Bali (Colenbrander \& Coolhaas 1953: 414-5). The latter was surrounded by splendour and much ceremony. At his side were an executive regent (patih) and a hereditary senior Brahmana priest. The ruler had an important economic asset in Lombok, was sometimes the overlord of Blambangan (easternmost Java), and lodged pretensions over Sumbawa. The VOC records also show that the island broke up in mutually quarrelling kingdoms in the second half of the seventeenth century, a pattern that remained until the colonial conquest in 1906-08 (Hägerdal 1998). The mainly Muslim Lombok underwent a somewhat different trajectory since it was subjugated by one of the Balinese micro-states, Karangasem, and eventually brought under the unitary rule by a Karangasem dynastic branch in 1839-94.

The nature of the pre-colonial Balinese state is much debated. The well-known study by Geertz about the late pre-colonial era postulates a kingship that was obsessed with pomp and glory as an end in itself and wielded limited influence over local society. The desa (villages), banjar (hamlets) and subak (irrigation organizations) were partly overlapping entities that were managed locally. Although the royal centre and aristocracy gathered taxes based on irrigation, there was no true congruence between political authority, land tenure and distribution of land tenancy; rather, the management of agricultural production was largely autonomous from the exercise of royal power (Geertz 1980: 45-86). Stephen Lansing has developed the theme further, arguing that the crucial irrigation works that underpinned the production had an organizational structure centred on temples, with one centre in Batur in the highland. He found traditional state power weak and detached from the work of the peasants, and argued that the island had never been politically united before colonialism (Lansing 1991). These views have been countered by Henk Schulte Nordholt and Brigitta HauserSchäublin, who have both found indications in the sources of royal intervention in local agricultural affairs. While the land was believed to belong to the gods, the aristocracy did have means to exert influence on the peasantry through control of irrigation works (HauserSchäublin 2003: 153-81; Schulte Nordholt 2011: 21-7). At the same time, Schulte Nordholt emphasizes the decentralized nature of the Balinese polities: satellites ruled by aristocratic families tried to replicate and emulate the exemplary centre, and would easily break away from the central court. From another perspective, J.-F. Guermonprez has followed a process of relative de-indianization and de-sacralization of kingship on Bali from the medieval period up to late pre-colonial times. With the transition to smaller competing states in the seventeenth century, the texts bear witness to a more active type of kings whose personal prowess and violent exploits grant prosperity to their realms. Still there is a strong sacred or spiritual element, kasaktian, in late kingship (Guermonprez 1985: 39-70). Finally, one may 
mention the comprehensive study of Margaret Wiener who has emphasized the importance of magic and supernatural beliefs for the prestige of a Balinese dynasty, in this case the prestigious Dewa Agung line of Klungkung which held a precedence position on Bali up to 1908 (Wiener 1995). Neither Guermonprez nor Wiener says much about the economic and administrative underpinnings of royal power, however.

\section{Sumbawa: stability and ethnic bifurcation}

To the east of Lombok, Sumbawa offers an interesting and little-studied picture of a set of six minor states that co-existed from at least c. 1600 to the early Indonesian republic in the 1950s. The island is on average much less fertile than Bali and Lombok. Moreover, it is ethnically and geographically divided into two parts. The eastern half constituted the kingdom (sultanate) of Sumbawa (Proper) and has a language related to Sasak, the majority language of Lombok. The eastern half speaks an entirely different Austronesian tongue and was traditionally divided into the kingdoms of Bima, Dompu, Sanggar, Tambora, and Pekat the last two exterminated by the infamous Tambora eruption of $1815 .^{3}$ Communication between the two halves was impossible along the south coast, and less than comfortable in the north.

However, although it was politically and ethnically split, the six-states-system was in a sense more successful than the nine rival kingdoms of Bali or the realms and factions of Lombok. To be sure there were a number of internal and external conflicts over the centuries, but they were fewer and briefer than the perennial warfare on Bali - a reminder that ethnic unity does not automatically means greater stability. Part of the explanation lies in the checks exerted by external suzerains - the Makassar kingdom was the overlord of the island from $1618 / 19$ to 1667 when the VOC took over (Noorduyn 1987). Nevertheless, colonial control was weak and only had a symbolic presence up to 1905 , and it is therefore plausible that the six kingdoms emerged as relatively stable units at an early stage, unlike the ever-changing political landscape of Bali and Lombok.

So far there is not too much research about the historical evolution of the Sumbawan kingdoms, in spite of important observations by Henri Chambert-Loir and a couple of local scholars. A problem here is the textual sources. While there are a few Hindu-Javanese inscriptions that indicate Majapahit influences, the preserved histories only give the postIslamization perspective (De Casparis 1998). In Bima, the Sumbawan kingdom which preserved the most elaborated traditions, we learn that a loose, territorially organized federation was replaced by a Hindu-styled dynasty, ten generations before 1600. From an early Portuguese source we know that the Bima kingdom existed by 1515 (Cortesão 1944: 203). A governing body (hadat) was formed by means of oaths and obligations where the sangaji (raja) and his executive regent had to balance a number of territorial ncuhi. A local historian likened the system to Western feudalism (Tajib 1995: 76). The population was divided into some 70 hereditary guilds which were connected to the royal centre or certain title-holders by obligations of services (Chambert-Loir 1993: 80-1). In the western kingdom of Sumbawa (Proper), the ruler was seconded by a council (tana' samawa) with partly

3 Andaya 1981, map 7. The people of the Tambora kingdom spoke a separate language, unrelated to the other two, now extinct. 
Javanese-sounding titles, and two governing councils of $5+7$ grandees. Land was controlled by the nobility, but the low population density meant that arable land was fairly available to the population. He also had to reckon with three largely autonomous vassals on the west coast (kemutar telu) (Manca 1984: 66-87). A series of Makassarese military expeditions in 1618, 1619 and 1626 turned the Sumbawan kingdoms into vassals and enforced the adoption of Islam, which led to new impulses in the administrative development of the kingdoms. Islam is described in historical tradition as a crucial tool of political-social integration, since royal power upheld the task of disseminating the faith through a number of practices (Tajib 1995: 123-4; Noorduyn 1987).

From an economic point of view Bima is known to have been part of a larger archipelagic network stretching from Melaka to Maluku by the early sixteenth century. Among Sumbawan export products were horses, sappan wood and rice (Chambert-Loir 1993: 86). Slaves were brought from Manggarai and Sumba where Bima had political interests since perhaps the mid-sixteenth century.

\section{The spice sultanates: inter-insular networking}

Of the four kingdoms of North Maluku - Ternate, Tidore, Bacan and Jailolo - the two firstmentioned are better documented than the preceding areas, thanks to early curious Iberian writers, and later scrupulous VOC records. Historical traditions speaks of a four-division originating with four brothers who gave rise to the respective royal lineages. Thus Ternate was supposedly founded ten generations before the first documented ruler in 1512, and Tidore reportedly had nine rulers before that date. ${ }^{4}$ The early, pre-islamic history can nevertheless not be substantiated. From various Iberian writers we can conclude that Islam gained the position as the religion of the rulers around 1435-1470, although it exerted an uneven influence on the local populations (Van Fraassen 1987 I: 32-3).

In contrast with the two previous regions, the North Maluku island kingdoms had an economic asset that gave the islands a global significance. The beginning of what Anthony Reid calls Southeast Asia's age of commerce in the fifteenth century made for an upsurge of trade in spices, whereas the coveted cloves were merely found on a number of minor islands in North Maluku including Ternate and Tidore. That made for a refined local organization of sellers and buyers, at about the same time as Islam was accepted by the rulers and transformed into sultanates. It also provided an international flavour of the elite culture. A Portuguese treatise from c. 1544 in particular points at Malay influences. By this time Malay had become the "Latin" of the region, and people dressed in the Malay fashion. However, Javanese influence could also be seen in some official titles and musical instruments, while Chinese import goods were widely used (Jacobs 1971: 75, 108, 112, 123).

The early Iberian writers portrayed the sixteenth-century sultans as lacking in conventional powers, although this might have been a grave underestimation of their symbolic role and functions. The smaller units of the kingdoms were autonomous, and the king/sultan was a primus inter pares rather than a world ruler of the Indic type. The spice sultanates were like systems of alliances rather than conventional states. With the onset of Portuguese influence

4 Genealogies of Ternatean rulers are found in Van Frassen 1987, Vol II: 1-30. For early Tidorean rulers, see De Clercq 1895, Appendix. 
after 1512, and the preponderance of the VOC after 1606, kingship seems to have changed substantially: on the one hand increasingly dependent on European dispositions, but on the other hand with enhanced internal power resources thanks to European diplomatic recognition and assistance.

Two of the sultanates, Ternate and Tidore, expanded their influence greatly over Central and South Maluku, the Papuan coast-lands, much of Sulawesi, and the Solor and Alor Islands. Much of this expansion took place after the arrival of the Europeans. In many Malukan islands there was a division between two bonds of settlements known as Uli Siwa and Uli Lima (the nine- and five-bonds) which was attributed to the rivalry between Ternate and Tidore, although this may have to be qualified..$^{5}$ There was a core area of Ternatean dependences (the Ambon Quarter) where noble Ternate families acted as sub-rulers, but for the rest the conquered areas tended their own business as long as they acknowledged the suzerainty of the sultan (Andaya 1993: 83-4). In fact the connections between the core islands of Ternate and Tidore and their dependencies were clearly tenuous, perhaps often being pretensions rather than implying actual influence. Local traditions on far-away islands such as Solor and Alor nevertheless credit Ternate with significant cultural influences, such as the early introduction of Islam. Also, Tom Goodman, researching trade networks within the Tidore sultanate, has recently pointed to the "social interaction of exchange networks as unifying factors in regions with elastic competing 'centres"” (Goodman 2006: 7).

\section{The Timor region: ritual alliances and the role of sandalwood}

The fourth region under scrutiny has both similarities and important differences with the preceding ones. The island of Timor and the regions in its vicinity - East Flores, Savu, Rote, Solor, Alor - were not subjected to foreign cultural influences in the same fashion as BaliLombok, Sumbawa, and North Maluku. Indian culture is absent in the area, and Javanese influences were weak. Islam played a role in some parts of the Solor and Alor Islands, mainly through Ternatean influence, and Makassar held a degree of authority in the region up to 1667. ${ }^{6}$ The dominant powers after the early 1600s were however Christian; Portugal and the VOC strengthened their positions over the century and kept Indonesian competitors away. The main reason for this European activity was sandalwood, an item that grew in considerable quantities on Timor and gave the dry and resource-scarce island a wider commercial importance. It is mentioned in medieval Chinese geographical texts, but the large-scale sandalwood trade may have taken off with European (Portuguese) influence in the sixteenth century. ${ }^{7}$

The kingdoms, or rather realms which flourished on Timor and its neighbours were rather formed according to older Austronesian concepts of power and authority - partly known in the other three regions under scrutiny. Very little is known about them from contemporary records before the seventeenth century. Society, as described by somewhat later Western

\footnotetext{
5 It has been argued that the Uli Siwa-Uli Lima division was disseminated to the southern parts of Maluku indirectly, without any direct Ternate or Tidore impact (Van Fraassen 1987 II: 460-85).

6 Rodemeier 2006 notes the importance of Ternate as an imagined cultural and ordering force on protohistorical Pantar (Alor Isands).

7 De Roever 2002 is the main work for the development of the early-modern sandalwood trade.
} 
travellers and ethnographers, was based on symbolic dualism and quadripartition and paid great attention to cardinal directions, the construction and position of houses, and the role of ancestors and origins. The ruler of a kingdom was usually a non-active, symbolically "female" figure who was complemented by a "male" holder of executive powers, and a host of functionaries whose prerogatives varied from kingdom to kingdom. ${ }^{8}$ Society consisted of several social layers, in East Timor known as datos (princes), tumengões (chiefs), commoners and ate (slaves). The distinctions were strictly upheld in theory, but frugal economic conditions resulted in relatively small differences in the actual living conditions. ${ }^{9}$

The kingdoms were small-sized, with populations that ran in the thousands rather than tens of thousands. Some 70 kingdoms existed on Timor in the early-modern period, about 19 on Rote, 6 on Savu, 5 on the Solor Islands, and about 9 on the Alor Islands. ${ }^{10}$ Nevertheless there were larger bonds or realms that encompassed wide areas. Wewiku-Wehali in the fertile plain of south-central Timor was known as a nexus of Timorese political culture up to modern times, and seems to have emerged before the early sixteenth century. A Portuguese missionary account alleges that the lord of Wehali was honoured like an emperor by the minor rulers all over Timor, at least before it was wrecked by Portuguese military expeditions in 1642 and 1665. Other accounts speak of three "unique kings" who ruled Timor in preEuropean times, namely Sonba'i in the west, Wehali in the middle and Likusaen (or Camenaça) in the east, where Wehali was understood to have a position of precedence (Hägerdal 2012: 62-4; Castro 1867: 205, 243). There was also a bond between the five Solorese polities called Watan Lema (the five shores) and another one between five Alorese ones known as Galiyao (Barnes 1995: 499; Rodemeier 1995: 438-42). Sometimes these were considered to be included in a larger bond of ten. None of these bonds seems to have enjoyed much internal cohesion, since wars between the smaller components are frequently mentioned in archival sources and local traditions. The general image is one of political fragmentation which was seldom remedied by calls of unity in the face of foreign encroachment. Nevertheless we should not underestimate the ideological importance of the bonds or realms. As pointed out by James J. Fox, there is an interesting paradox in the central position of Wehali whose ruler was ritually inactive ("eating - drinking - sleeping") and seldom seen by outsiders; at the same time he was evidently honoured in most places of Timor over the course of several centuries, though largely ignored by the European powers (Fox 1982). The invisibility and modest appearance of this "dark lord" is an intriguing counterpart to the paraphernalia and state rituals of the Balinese rulers described by Geertz (1980).

\footnotetext{
8 See in particular Schulte Nordholt 1971, drawing on principles of structural anthropology.

9 The Timorese prince and researcher Alexander Un Usfinit (2008: 58-9) has described the very elaborate hierarchy of clans and functionaries in his home domain, Insana. Under the ruler or atupas are nine categories of clans in hierarchical order with various functions: supporting clans, warrior clans, custodian of the land clans, etc. Lists of rajas and polities in the late colonial period under Dutch suzerainty are found in Van Dijk (1925, 1934). The East Timorese rulers and kingdoms are surveyed in Belo 2013.

10 Maps showing the more significant ones are found in Hägerdal 2012: 63, 79.
} 


\section{Comparison between the four regions}

How did polities in Bali-Lombok, Sumbawa, North Maluku, and the Timor region emerge in the fourteenth through seventeenth centuries? A fundamental problem is that contemporary sources, or extensive chronicular traditions, fail us. While the mainland kingdoms during this era also suffer from a relative dearth of sources, a combination of chronicles, Chinese and European texts, epigraphy, and archaeology, enables us to study these societies in some detail. For eastern Indonesia we are less fortunate. The only region under scrutiny where we have extensive records from the early sixteenth century is North Maluku, due to the enormous importance accorded to the acquirement of spices by European writers. ${ }^{11}$ For the remaining three we have to draw conclusions from VOC records of the seventeenth century and later, and from much later chronicles and traditions. ${ }^{12}$

Victor Lieberman speaks of "charter polities", meaning early states that roughly defined the idea of an area as a territorial and cultural entity (such as the Khmer Empire, Pagan, pre1407 Đai Viêt, etc.). The only region where such thing can be documented is Bali, where epigraphical records clearly show the existence of a kingdom from late ninth century to 1343. ${ }^{13}$ However, historical tradition has retained few memories of this, and rather traces the cultural roots of Balinese life back to the Javanese kingdoms, especially Majapahit (Berg 1927: 93-121). Nothing of that sort can be documented for Sumbawa, although some of the local kingdoms, such as Dompu and Bima, seem to have existed in some form in the fourteenth century (Hitchcock 1996: 30). Ternate may have arisen as an entity above chiefdom level with the upsurge of the spice trade and the coming of Islam, in spite of claims that its kingship goes back to the thirteenth century. ${ }^{14}$ For the Timor area we cannot really say much since there are utterly few written sources before 1500 , or even 1600 . If there is any truth in the legends of Melaka influences on the emergence of Wewiku-Wehali, the latter would have arisen between 1400 and 1522 (Hägerdal 2012: 64-5). The emergence of increasingly tightly organized polities in these centuries ties in with the possible effects of resource accumulation conditioned by long-distance trade; but also with climatic data as established by scientific methods. In the period c. 1100-1400, eastern Indonesia appears to have suffered increased El Ninõ-related effects, followed by a relative stable period until a new disturbed period in the mid-seventeenth century (Chao 2008: 245).

The real and mythological roles of strangers are an interesting theme that seems to link the emergence of the four regions together. Anthropologists and historians have recently emphasised the so-called stranger king syndrome in the eastern part of the Southeast Asian archipelago: a propensity to refer to the founders of traditional polities as strangers coming from outside. These strangers have founded the present hierarchical order and ruling structure, and their strangeness is seen as functional because of their position as bringers of culture and ability to mediate between particularistic interests, such as different clans (Barnes 2008; Fox 2008). The Balinese kings of Gelgel, and the Ksatria and Wesia nobles,

11 The narrative sources up to the early seventeenth century are summarized in Tiele 1877-87.

12 Not forgetting the hitherto relatively untapped possibilities offered by archaeology; for a recent attempt to use gravestones to fill out our knowledge of precolonial and early colonial history on Timor, see McWilliam et al. 2012.

13 The Balinese ancient kingdom is traced in Kempers 1990, chapter 3.

141257 according to the calculation of François Valentijn; see Van Fraassen 1987 II: 2. 
supposedly came from Java at the height of the Majapahit Empire, while a Brahmana clan helped the second king of Gelgel to stabilise his realm in the sixteenth century (Warna 1986: 63-4, 78-81). According to West Sumbawan tradition the early rulers of Sumbawa Proper, Seran, and Selaparang on Lombok were descended from Sunan, probably meaning the Muslim lord or sunan of Giri on the Pasisisir coast of Java (Manca 1984: 26). The East Sumbawan chronicles trace the sultans of Bima and Dompu from the hero Bhima of the Mahabharata epic, who in this version would have come from or via Java (Tajib 1995: 42-5, 51-9). The rulers of Ternate, Tidore and the less powerful Jailolo and Bacan claimed descent from an Arab, Jafar Sadik (Van Fraassen 1987 I: 16). The Timorese origin stories are more varied, but many ruling lineages supposedly came from Wehali which in turn hailed from Sina Mutin Malaka, "White China Malaka" (Grijzen 1904: 53). This mytho-geographical term seems to combine two points of origin for external traders, and indeed mirrors the situation around the fifteenth century: from Malacca, which enjoyed Ming Imperial protection, sandalwood exported from the Timor area was trans-shipped to China and other places (Chao 2008: 36). For Bali-Lombok, Sumbawa and the spice sultanates the religiouscultural ramifications of the origin stories are obvious, with strangers representing HinduJavanese and Islamic influences. While the historicity of the stranger king pedigrees are up to debate, credible accounts tell of strangers being present in or near the court in the four regions under scrutiny during the age of commerce. Thus, Bali's oldest mosque is found in Gelgel, near the old court, which is matched by stories of early Muslim settlers (Vickers 1990: 168; Warna 1986: 84). People with a Malay identity lived in a kampung at the Bima Bay from an early stage. They enjoyed close relations with the sultan's court and had a role in disseminating Islam (Sjamsuddin 2013: 27-38). Javanese commercial and religious contacts with the spice sultanates are said to have existed since the fifteenth century. The first Muslim sultan married a princess or noblewoman from Java who was important for the propagation of Islam, and both Ternate and Tidore had Javanese soas (Van Fraassen 1987 I: 129, 428).

Of the four regions, Bali-Lombok possessed a pronounced tradition of literacy which, as shown by all inscribed and written charters, had a vital role in the execution of royal power. Javanese script was known on Sumbawa although we know little about the consequences, and the kingdoms later on adopted Jawi and Makassarese scripts (Hitchcock 1996: 43). The spice sultanates presumably knew Arab-derived script from the fifteenth century, though it may have had limited importance for state affairs. ${ }^{15}$ Such script was only very marginally known among the Muslims of Solor-Alor, and on Timor itself the elites were acquainted with Latin script in the seventeenth century, again very marginally. While European sources are clearly biased and rooted in Western conceptions of how a society worked, they seem to imply that administrative routines within the kingdoms (possibly apart from Bali) were normally handled without the issuing of written documents.

The geographical location of royal centres shifted much between the four, but the point of gravity was usually at or close to the coast. This may be less than surprising considering the modest size of most of the islands and the location of fertile areas downhill. Balinese historical tradition suggests however that the centre of the kingdom shifted from Samprangan 
in the inland to Gelgel close to the coast, perhaps in the decades around $1500{ }^{16}$ The six Sumbawan royal seats were also at or close to the shore, as were (of course) those of the tiny islands Ternate and Tidore, and the petty states of Solor-Alor. By contrast, the indigenous Timorese groups tended to keep away from the coast, although the central Wehali lay on a fertile plain within easy reach of the dangerous southern coast. Security concerns seem to have been decisive here; for example, a Dutch account from 1656 relates that the centre of the powerful Amarasi kingdom consisted of small settlements on hilltops. ${ }^{17}$

The kingdoms in the four regions were all heavily involved in trade. This is most apparent in the spice sultanates whose very creation was due to the location of Ternate and Tidore at one of the eastern terminal points of the net of trade routes that bound maritime Asia together. One trade route connected Maluku to Java and Melaka, while another route went towards the north and connected Maluku with mainland Southeast Asia and China via Borneo and the Philippines (Ptak 1992: 27-8). Through Ternate and Tidore the long-distance traders had indirect access to the lands further to the east and south, such as Papua and Aru, which offered massoi bark, birds of paradise, etc. (Warnk 2010: 110-1, 115). Early European reports on Timor likewise indicate that the authority of Timorese rulers near the coast (such as that of Kupang) was underpinned by anchorage fees and trading fees. A recent archaeological investigation has suggested that increasing trade opportunities in the small Timorese polities made for increasing warfare and alliances, drawing early European intervention (Chao 2008: 254-5). The Timorese were, however, hardly active traders and let other groups handle the export. This pattern is also valid for Bali where the Gelgel ruler controlled the main entrepôt Kuta in the south via a sub-ruler. Traders from the Javanese pasisir purchased cloth on Bali to sell further to the east (Schrieke 1955 I: 20-1). Surplus manpower was exported as slaves. The connection between royal power and trade is less clear-cut on Sumbawa, though it is known that sappanwood was felled on royal initiative in the VOC period and delivered to the Company servants. ${ }^{18}$ Horses, sappan, rice, sandalwood, sulphur, and so on, are mentioned as trade goods by the sixteenth century; nevertheless the island had few truly important export items, presumably a contributing reason why it was largely left to its own devices.

In all the four cases the degree of centralisation and cohesion was weak within the territories claimed by the kingdoms, however with great variations. For example, Tidore was more troubled by internal rifts than its neighbour Ternate, and Sumbawa Proper much more than its neighbour Bima. Rebellions and usurpations by new lineages or side-branches are however attested in nearly all the known realms, which is not dissimilar to the situation in the larger Southeast Asian states. Royal rule expanded and contracted with the circumstances, and borders fluctuated much over the years. Ternate competed with Makassar over suzerainty over economically important areas on and around Sulawesi. Sumbawa Proper competed with the Balinese over influence on Lombok while Bima vied with Makassar for overlordship over Manggarai and tried to maintain a degree of influence on Sumba (Hitchcock 1996: 33-4).

16 The traditional history of Samprangan and Gelgel is traced by Berg (1927: 103-67) who however believed that Samprangan was replaced by Gelgel earlier, in the fourteenth century. The date 1380 found in some textbooks is based on speculation and has no value.

17 VOC 1217, f. 332r-332v, 1.04.02, Nationaal Archief, Den Haag.

18 De Jong Boers 1997: 261-80. Rice from Bima did have a role in parts of Maluku, however, and the rice production might have been a contributing reason for the Makassarese conquest in 1618-26. 
Balinese suzerainty over East Java, Lombok and Sumbawa also fluctuated a lot during the sixteenth and seventeenth centuries. The major realms on Timor, such as Sonba'i, underwent great territorial changes due to inner and outer conflicts. The more sizeable eastern Indonesian realms were therefore characteristically "contest states" where vertical relations between the centre and constituents had to be reconstructed or reinforced from time to time. ${ }^{19}$

The royal centres were characterized by architectural symbolism and ritualised institutions that underlined their power and charisma as so-called exemplary centres - politico-cultural centres that the satellites/dependencies tried to emulate - but on very different levels. While Gelgel's satellites on Bali, East Java and Lombok replicated Indic models, Bima's dependencies on Flores and Sumba did not emulate its Muslim or Indic features. As for the far-flung satellites of Ternate and Tidore, some did take up miniature versions of the MuslimMalay court culture, including the principalities on the Papuan Islands (Warnk 2010: 112-3). Tidore's image as an Islamic exemplary centre was sufficiently strong for stories to circulate in faraway places like Aru, where the sultanate had no formal power. ${ }^{20}$ On Timor the central Tetun-speaking kingdom of Wehali, although lacking strong control mechanisms, made a great cultural impression on polities all over the island, which was more a matter of symbolic deference than real political subordination. ${ }^{21}$ The cosmic model of Southeast Asian statecraft is therefore selectively applicable to eastern Indonesia. There are hardly any palaces left from the early-modern period, but preserved descriptions indicate that extensive puri compounds existed on Bali in the sixteenth century, comparable with those known in modern times. Several temples known on Bali today have alleged roots back to ancient times, and some, most famously the Pura Besakih, are closely linked to the old Gelgel kingship (Wiener 1995: 122). The royal compounds of Sumbawa, the spice sultanates, and Timor, appear to have been of comparatively modest dimension and built in perishable material. We may get an idea of the variations from the well-preserved Dalam Loka of Sumbawa Besar with its barnlike structure, and the small beehive-shaped sonaf (residence) of Insana on Timor. In no case were the residences located in proper towns. Typically, they would be surrounded by the hamlets of royal artisans and servants, in turn surrounded by residential areas for merchants and poorer people (Hitchcock 1996: 75-82).

Perhaps the most important question to be posed in this context is the ability of the royal centre to reach out to the components of the realm. Did the rulers have the prerogatives or means to secure the delivery of taxes, tributes, and fees? Or did their actual power depend on other sources? As mentioned before, there are irreconcilable differences in opinion between scholars with regard to the efficacy of Balinese royal rule. However, scholars who have scrutinised both historical sources and anthropological data seem to have identified administrative cycles of expansion and contraction. Thus the Gelgel kingdom may have

19 For the contest state, see Schulte Nordholt 1996: 4-10.

20 Emilie Wellfelt, Linnaeus University, personal communication. In a later case, from the 1780s, the Arunese heard and believed that Tidore had the power to eradicate the European possessions and impose Muslim rule in the region; see VOC 8034, Report Nicolaas Harmansz, 1.04.02, Nationaal Archief, Den Haag.

21 This is in particular visible in the oral traditions from West and East Timor collected by the Australian scholar Peter Spillett in the 1990s, in his unpublished manuscript "The pre-colonial history of the Island of Timor together with some notes of the Makassan influence in the island" (Darwin, 1999). The majority of all the traditional domains, from Kupang in the west to the Falaluku-speaking area in the east, have references to Wehali influences. 
flourished for about a century and a half, from the decline of Majapahit in the early sixteenth century to its own decline in the period between 1651 and 1686. The sources give the impression that the principal ministers, taken from a particular clan, were the main wielders of executive power, rather than the person of the king. In spite of the Indic inspiration of the cultural manifestations, this is rather similar to the division of authority on Sumbawa and Timor, as we shall see. Gelgel was followed by a series of shorter hegemonies, such as Buleleng in the late seventeenth and early eighteenth centuries, and Mengwi for much of the eighteenth century. ${ }^{22}$ During their heyday, these hegemonies may have been able to control the main paddy irrigation areas through effective cooperation with local lords (manca, punggawa) who in turn oversaw and taxed the irrigation works of the rice peasants. It has been suggested that the banjar (wards) of the Balinese settlements were introduced by the royal authorities in the post-classical period to ensure the duties of the peasantry; they were headed by klian or headmen appointed by the rulers (Vickers 1989: 47-8, 218). The military capabilities of the Gelgel elite were considerable, with an elite force and levies that reportedly reached 20,000 people, although such figures must be considered vastly exaggerated (Berg 1927: 153-5). The fragility of the system is nevertheless obvious, as seen by the rapid breakdown of successive hegemonies.

The capabilities of the Sumbawan kingdoms to control the local scene were limited, but the apparent stability of the institutions after the coming of Islam, and especially after the contracts with the VOC, may have petrified exchange relations to the benefit of the six royal centres. To take the example of Bima, there was a rather pronounced system of social ranks where the princely estate and the nobility were major landowners. The commoners were organized in dari (genealogical groups somewhat similar to guilds) with obligations towards the royal centre. Much of this may be attributed to Javanese, Malay and Makassarese influences, but there are also aspects that point to older political structures. Bima has been likened to the small polities on the non-Islamic Sumba as a case of "dual monarchy". The sultan was the revered central figure but was not originally expected to be an active one, and the ruma bicara or prime minister was the active, secular prince (Hitchcock 1996: 77). Henri Chambert-Loir, studying court diaries, has noted that the material seems to support the idea, common among modern Bimanese, of a relatively strong local voice vis-à-vis the governing centre. Thus village heads might gather before the sultan and demand action against corrupt functionaries, even if closely related to the sultan (Chambert-Loir 2010: 44). Locally, a custodian of the land, malar, took care of agricultural rituals and the distribution of land (Hitchcock 1996: 75). This is similar to functionaries in several eastern Indonesian societies, such as the tobe on Timor (Schulte Nordholt 1971: 186-8).

The case of the spice sultanates is more complicated since it involved external economic relations to a much higher degree than on Bali-Lombok and Sumbawa. As shown by Christiaan van Fraassen, the organization of the societies of Ternate and Tidore was based on an idea of quadripartition, under which were settlement units called soa, somewhat similar to kampungs in western Indonesia but not based on kinship (Van Fraassen 1987 II: 693). The soas in various parts of Maluku share a few characteristics: they are the units of which a polity is based, they have hereditary chiefs recognized by the ruler, and deliver tribute or 
services to the royal centre. However, the extensive realms created by Ternate and Tidore also depended on interaction with outsiders, Asian and European groups who arrived to take advantage of the products of Maluku. Moreover, the peoples of Maluku often benefited from these commercial relations, something that helps explaining their inclusion in the far-flung realms. A rather dialectic relationship between integrative and autonomous forces in the polities can be discerned. In the example of Ternate we see that the royal council included 18 soa chiefs, who had a strong voice against the sultan in the sixteenth and part of the seventeenth centuries (Van Fraassen 1987 I: 343-4). However, the power of the sultans vis-àvis the local leaders increased under VOC suzerainty. Like on Bali, the sultan had a detachment of core troops, and could call up considerable additional troops in case of warfare. The subjects of Ternate and dependences would deliver a stipulated number of manned warships for defence or expansive enterprises (Van Fraassen 1987 I: 363-4). At the same time Christiaan van Fraassen has shown that the Ternateans themselves did not identify the state with the sultan's court, but rather saw the soa chiefs (bobato) as co-responsible for how the state was run (Van Fraassen 1987 II: 695). The PhD Thesis of Tom Goodman interestingly shows how a local category of traders known as sosolot maintained economic exchange and political cohesion in the Tidore realm, a fact largely unnoticed by the VOC suzerains - but at the same time they impeded the centrality of the sultan's power (Goodman 2006: 7) .

As for Timor and adjacent islands, the capabilities of the royal centres are much more "indigenous" in character than the other examples. The marginal role of Javanese, Malay and Islamic influences have a role here. To be sure, Christianity made inroads from the seventeenth century when Dutch and Portuguese political influence increased, but European impact on the structure of the petty realms was indirect and piecemeal. Western sources about early Timor are ambiguous about the capabilities of the rajas, describing them as despotic at times, but at times emphasizing their lack of executive powers. Ethnographic literature from the last two centuries describe a dual monarchy (akin to the one mentioned for Bima), and a rather intricate system of title-holders that reach down to the local hamlets. "Taxes" consisted of harvest gifts which were regularly provided to the princely centre. ${ }^{23}$ However, the documents show that the realms often lacked inner cohesion, as local temukungs (chiefs) and groups of commoners refused to obey the commands of the raja and regent. Timor's history is full of migration of smaller and larger groups due to political crises. Like in Sumbawa and the spice sultanates, European backing nevertheless strengthened the position of some realms.

\section{Eastern Indonesia and the major Southeast Asian kingdoms: protected and exposed zones}

In the first volume of his magnum opus, Strange parallels, Victor Lieberman has identified a number of characteristics for the major mainland states of Southeast Asia in the so-called post-charter era. They all fall into a period of political and cultural integration which had to do with the convergence of several factors: demography, agriculture, military factors, interstate competition, and foreign commerce. The emergence of Ayudhya, Lan Xang, the Lê

23 The anatomy of the traditional Timorese realms is analysed in detail in Schulte Nordholt 1971. 
regime of Đai Viêt, post-Angkor Cambodia, and the Toungoo Empire, was apparently reinforced by what Anthony Reid calls Southeast Asia's age of commerce (although some of these realms were founded before this age, as defined by Reid). The integration was characterized by a "growing standardization of ethnicity and cultural practice" (Lieberman 2003: 457). Although the integrative processes were broken by periods of crises (such as in Burma at the end of the sixteenth century and Đai Viêt for much of the same century), we can discern a general long-term move towards larger political units. In the early nineteenth century, before European colonialism disrupted the picture, there were only three major polities on the mainland. ${ }^{24}$

Some of this can be discerned in the Archipelago as well. Post-charter states such as Majapahit, Demak and Mataram, and states without any real charter predecessor, such as Aceh, Makassar and Ternate, governed over truly vast island realms (Reid 1993: 211-4). Here, both Islam and the classical Javanese models constituted vital frames for state integration. However, they suffered a deficiency that clearly set them apart from the mainland realms. The last-mentioned lay in a so-called protected rim zone. Like Japan, Arabia and western Europe, their geographical features made them less vulnerable to foreign military expansion (although the mainland kingdoms certainly invaded each other). The islands, too, were mostly free from foreign intervention up to the early sixteenth century. Then, however, the force of European maritime technology turned the island societies into an exposed zone where the Portuguese, Spaniards and Dutch all carved out spheres of political and commercial influence and even settlements.

One result of this was to disturb any development towards larger and more integrated archipelagic states. To be sure, the preconditions for such integration differed from the mainland due to the enormous number of small ethnic and linguistic groups, but it should be recalled that waterways were often less cumbersome lines of communication than land routes. The archipelagic states could uphold major spheres of influence by fleets of ships, but precisely this asset was ruined through the confrontation with the European seaborne powers. Only Ternate and Tidore in eastern Indonesia were able to keep large areas, but merely by complying with European demands for commercial surveillance. ${ }^{25}$

Had the European powers not disrupted the political structures of the Archipelago, the future of the minor polities of Bali, Sumbawa and Timor might have been in doubt. Bali was the subject of hostilities from both Java and Makassar, and at least part of Lombok was under Makassarese suzerainty for a while (Hägerdal 1998: 65-75). The Sumbawan kingdoms were increasingly drawn into the political system of Makassar in the seventeenth century, a process that was only interrupted by the Bungaya Treaty in 1667 that transferred suzerainty to the VOC (Tajib 1995: 132-7). Timor was on the verge of being subjugated by Makassar in 1641, but European interventions changed its political relations to the outside world. Ternate was a rival of Makassar, and it is a moot issue whether it could have held its own in the long run if Makassarese expansion had not been stymied by the VOC.

With the larger Archipelagic states weakened, however, the numerous small polities of eastern Indonesia were able to live on, often under VOC or Portuguese suzerainty that did not

24 Burma, Siam, and Vietnam; Laos and Cambodia being dependent on stronger neighbours.

25 The process is described in detail in Andaya 1993. To a lesser degree, this also applies to Bima with its (contested) claims on Flores and Sumba. 
interfere heavily with their inner structures. The Balinese, Sasak and (West) Sumbawan societies cultivated values and customs deriving from Java, which on Sumbawa were overlaid by Malay-Muslim and Makassarese traits. In that sense they were miniature versions of the Indianized statecraft of the mainland states and Java. This is seen in the sacred symbolism of the royal centre, the clearly defined hierarchy of social categories, and the legends and myths that accompanied the royal lineage. Similar to the rice-producing central basins of the mainland kingdoms and Java, rice was essential for the economic maintenance of Bali, Lombok and Sumbawa, while trade had a supporting rather than basic function. On the other hand, the lack of any real bureaucratic depth was even more pronounced than in the mainland and Java, in spite of the carefully named royal ministers and officials. The spice sultanates are different in the sense that they owe more to an interesting mix between traditional structures and Malay-Islamic influences, with comparatively less Javanese input (although the very name for a prince, sangaji, is Javanese). ${ }^{26}$ Timor, finally, is peculiar by its relative lack of either Malay-Islamic or Indic-Javanese input. In North Maluku as well as Timor, the agricultural base was comparatively weak, which sets them apart from the mainland/Java pattern.

\section{Conclusion: major realms versus petty kingdoms}

To sum up the discussion, we may ask if the integrative processes that Victor Lieberman identified with regard to mainland Southeast Asia can somehow help us to understand the history of the small kingdoms of eastern Indonesia. Perhaps it encourages us to realize that these polities are not cut in stone, unlike the impression that structural anthropology might have given us. While they surely display archaic features, partly observable until recent times, their preconditions were greatly changed when island Southeast Asia changed from a protected to a vulnerable zone in the sixteenth and seventeenth centuries or thereabout (Ptak 1992: 46-7). The efforts of the European sea powers to defeat political rivals and regulate trade to their own advantage halted attempts at multi-island integration by relatively resourcerich states such as Aceh, Mataram and Makassar, and gave the eastern princedoms a respite up to the true implementation of colonial rule in the early twentieth century.

To compare the post-charter mainland states that arose in the fourteenth through sixteenth centuries with the small polities east of Java may seem rash, but the question must nevertheless be posed: what elements underpinning the integration of the larger states are also valid for eastern Indonesia? The Gelgel kingdom of Bali, the main Sumbawan kingdoms, Ternate, Tidore, and (presumably) the major realms of Timor arose in about the same period, and it is hard to see this as a coincidence. Reid has pointed out a number of factors which underpinned the rise of port polities in various parts of Southeast Asia in the fifteenth century, followed by state formation in what he calls "the long sixteenth century". These included increasing trade revenues, bound up with the Chinese impact, and the import of advanced military technology (Reid 1993: 204-33). Lieberman has similarly argued that external input, such as the growing market demand in parts of Eurasia after 1400/1470, was crucial to bring economic and military advantages to privileged lowland areas (the Menam

26 The indigenous term for a king was kolano, a local word that was used parallel with sultan; see Van Fraassen 1987 I: $16,18$. 
basin, the Red River delta, Irrawaddy, etc.) (Lieberman 2003: 45). Population increase is given a considerable role in this model, underpinning inclusion in wider commercial networks. Densely populated core areas facilitated domination of outlying regions with sparse population. Technological novelties played a role; the use of firearms spread to Southeast Asia in this period. Culturally, world religions such as Buddhism and Confucianism increasingly helped stabilising the kingdoms in a process of cultural standardisation. Clifford Geertz among others has postulated the importance of a ritually laden court as an exemplary centre, which the satellites and dependencies of the polity tried to emulate (Geertz 1980: 11$5,58,109)$.

Some of this is no doubt present in eastern Indonesia, but on a very uneven scale. Demographic developments are not traceable, but at least early European reports confirm the unusually dense population of Bali by the late sixteenth century, no doubt a major reason for its ability to hold its own against Muslim neighbours. East Sumbawa is likewise said to have been densely populated by 1515 (Cortesão 1944: 203). Population in parts of eastern Indonesia may have increased due to the early import of American crops, such as maize (after c. 1540) (Boomgaard 1997: 419). The general rise in long-distance commerce after the founding of Melaka in c. 1400 was probably crucial for the development of statecraft, and accompanied by cultural imports. The impact of the market demand is most obvious in the spice sultanates, but all four regions were involved in long-distance trade that may have benefited the core areas of the respective realms and even enabled limited import of weapons technology - at least, muskets and cannonry were known in Gelgel by the late sixteenth century (Lintgensz 1856: 207). These core areas were usually situated in comparatively fertile or productive parts of the islands at or near the coast (Gelgel, Sumbawa Besar, Bima, the Ternate and Tidore courts, Wehali). Comparatively stable climatic conditions between the early-fifteenth and mid-seventeenth centuries supported the integration of such core areas. Unlike the mainland and Java, river basins played no major role here. The stranger king syndrome found in the four areas speaks for the importance of foreign influences and again reminds us that the eastern Indonesian realms were insular but not isolated. In fact this syndrome sets them apart from the mainland states and Java where the ruling elite was usually seen as autochthonous.

Apart from Timor, advanced external religious systems played a great role to legitimize the polities: Hindu-Javanese concepts in Bali and early Lombok and Sumbawa, Islam in Lombok, Sumbawa and the spice sultanates. Like on the mainland, religion played an integrating role in the stabilization of the realms, as seen in the great expansion of Ternate in the sixteenth century. Nothing of this sort can be discerned for Timor, although it could very well have gone that way: Islam was accepted by the central ruler of Wehali in about 1641 when he briefly allied with Makassar, although the islamization project was abruptly impeded by the Portuguese (Hägerdal 2012: 85-90). The major eastern Indonesian courts accord to some extent with the model of the exemplary centre discerned in many "galactic" or "cosmic" polities of Asia. This is seen in the importance of Gelgel (and its Majapahit roots) in the Balinese view of the past, as well as the awe in which Ternate and Tidore stood in various parts of the archipelago as sources of culture and Islamic propagation. Interestingly 
the Timorese realms of Wehali and Sonba'i held similar roles in spite of their limited governing power, as seen by their great role in traditions all over the island. ${ }^{27}$

Anthony Reid and later Victor Lieberman have shown that the period after 1400 was a period of dynamic political, economic and cultural change, partly driven by the increasing commercial connectivities that linked parts of the "Old World" (Reid 1988-93; Lieberman 2003-09). In that sense the term "early-modern" is not the Eurocentric concept it is sometimes portrayed as, but on the contrary applicable to much of Asia. While small and vulnerable, the states of eastern Indonesia fall in line with their larger mainland and Javanese counterparts in some important respects. That should not detract from the fact that there were fundamental geographical differences. Maritime Southeast Asia was a semi-Mediterranean region where multiple civilisations interacted, migration and commercial activities were relatively feasible, and major realms were often characterized by strong maritime power unlike Toungoo, Ayudhya, Đai Viêt and inland Java (Wang 2012: 72). For the islands to the east of Java, a number of realms arose around the same time as the mainland states in 1400/1600, and partly for similar reasons. The sea-roads may often have offered more obvious means of exchange and communication than the cumbersome land-roads of the mainland kingdoms and Java; still, the fragmented ethno-linguistic picture complicated integration and expansion of the eastern Indonesian realms. The arrival of profit-driven European groups, and the ensuing sharpening competition between these and Muslim polities, made the area volatile and open to fast changes - but also offered chances of political survival under modest or subdued circumstances. Sometimes the process even strengthened the prerogatives of the rulers. The princedoms of the four studied areas would survive as archaic entities until the tempests of the twentieth century.

\section{References}

\section{Unpublished sources}

Spillett, Peter (1999), "The pre-colonial history of the Island of Timor together with some notes of the Makassan influence in the island". Unpublished manuscript, Darwin.

VOC Archive, Nationaal Archief, The Hague. Access number 1.04.02.

\section{Published sources}

Andaya, Leonard Y. (1981), The heritage of Arung Palakka: A history of South Sulawesi (Celebes) in the seventeenth century. The Hague: M. Nijhoff.

Andaya, Leonard Y. (1993), The world of Maluku. Honolulu: University of Hawaii Press.

Anderson, Benedict (2006), Language and power: Exploring political cultures in Indonesia. Jakarta: Equinox.

Barnes, Robert H. (1995), "Lamakera, Solor: Ethnohistory of a Muslim whaling village of eastern Indonesia", Anthropos 90: 497-509.

Barnes, Robert H. (2008), "The power of strangers in Flores and Timor", Anthropos 103: 343-53.

27 As noted above the occurrence of Wehali stories all over Timor can be seen from the unpublished study by Peter Spillett, "The pre-colonial history of the Island of Timor together with some notes of the Makassan influence in the island"' The same study shows that Sonba'i was a dynastic term known in most regions of West Timor. 
Belo, Dom Carlos Filipe Ximenes (2013), Os antigos reinos de Timor-Leste: Reys de Lorosay e reys de Lorothoba, coronéis e datos. Porto: Porto Editora.

Berg, C.C. (1927), De middeljavaansche historische traditie. Santpoort: Mees.

Boomgaard, Peter (1997), "Gevolgen van de introductie van nieuwe landbouwgewassen (1600-1900)", Spiegel Historiael 32-1: 418-23.

Casparis, J.G. de (1998), "Some notes on ancient Bima", Archipel, 56: 465-8.

Castro, Affonso de (1867), As possessões Portuguezas na Oceania. Lisboa: Imprensa Nacional.

Chambert-Loir, Henri (1993), "State, city, commerce: the case of Bima", Indonesia 57: 7188.

Chambert-Loir, Henri, et al. (2010), Iman dan diplomasi: Serpihan sejarah kerajaan Biima. EFEO: Jakarta.

Chao, Chin-yung (2008), "A Microregional approach to the social dynamics in the late prehistoric Manatuto, East Timor, eleventh - eighteenth century". Unpublished PhD Thesis, University of Washington.

Claessen, Henri J.M. and Jarich G. Oosten (1996), "Introduction”, in: Henri J.M. Claessen and Jarich G. Oosten (eds), Ideology and the formation of early states. Leiden: Brill. Pp. 1-23.

Clercq, F.S.A. De (1890), Bijdragen tot de kennis der Residentie Ternate. Leiden: Brill.

Colenbrander, H.T. \& W.Ph. Coolhaas (eds) (1953), Jan Pieterszoon Coen; Bescheiden omtrent zijn bedrijf in Indië, Vol. VII, 1. The Hague: M. Nijhoff.

Cortesão, Armando (ed.) (1944), The Suma Oriental of Tomé Pires, Vol. I-II. London: Hakluyt Society.

Diamond, Jared (1997), Guns, germs and steel: The fate of human societies. New York \& London: Norton \& Co.

Dijk, L.J. Van (1925, 1934), "De zelfbesturende landschappen in de Residentie Timor en Onderhoorigheden", Indische Gids 47: 528-40, 618-23, 56: 708-12.

Fox, James J. (1977), Harvest of the palm: Ecological change in eastern Indonesia. Cambridge, Mass.: Harvard University Press.

Fox, James J. (1982), "The great lord rests at the centre", Canberra Anthropology, 5,2: 22-33.

Fox, James. J. (2008), "Installing the 'outsider' inside: The exploration of an epistemic Austronesian cultural theme and its social significance", Indonesia and the Malay World 36: 201-18.

Fraassen, Christiaan Frans van (1987), "Ternate, de Molukken en de Indonesische Archipel. Van soa-organisatie en vierdeling: een studie van traditionele samenleving en cultuur in Indonesië", Vol. I-II. Unpublished PhD Thesis. Leiden: Leiden University.

Geertz, Clifford (1980), Negara: The theatre state in nineteenth-century Bali. Princeton: Princeton University Press.

Goodman, Thomas (2006), "The sosolot: An eighteenth century East Indonesian trade network". Unpublished PhD Thesis. Honolulu: University of Hawaii.

Graaf, H.J. De (1949), "Goesti Pandji Sakti, vorst van Boeleleng”, Tijdschrift voor Indische Taal-, Land- en Volkenkunde 83, 1: 59-82.

Grijzen, H.J. (1904), "Mededeelingen omtrent Beloe of Midden-Timor", Verhandelingen van het Bataviaasch Genootschap 54: 1-145.

Guermonprez, J.-F. (1985), "Rois divins et rois guerriers: Image de la royauté à Bali", L'Homme 25, 95: 39-70.

Hägerdal, Hans (1998), "From Batuparang to Ayudhya; Bali and the outside world, 16361656", Bijdragen tot de Taal-, Land-en Volkenkunde 154, 1: 55-94.

Hägerdal, Hans (2012), Lords of the land, lords of the sea: Conflict and adaptation in early colonial Timor, 1600-1800. Leiden: KITLV Press. 
Hägerdal, Hans (2015), "Eastern Indonesia and the writing of history", Archipel 90: 75-97.

Hauser-Schäublin, Brigitta (2003), "The precolonial Balinese state reconsidered: A critical evaluation of theory construction on the relationship between irrigation, the state, and ritual", Current Anthropology 44-2:153-81.

Hitchcock, Michael (1996), Islam and identity in eastern Indonesia. Hull: The University of Hull Press.

Jacobs, Hubert Th. Th. (1971), A treatise on the Moluccas (c. 1544): Probably the preliminary version of António Galvão's lost História das Molucas. Rome: Jesuit Historical Institute.

Jong Boers, Bernice de (1997), "Sustainability and time perspective in natural resource management: The exploitation of sappan trees in the forests of Sumbawa, Indonesia, 1500-1875", in Peter Boomgaard, Freek Columbijn and David Henley (eds), Paper landscapes: Explorations in the environmental history of Indonesia. Leiden: KITLV Press. Pp. 261-80.

Kempers, A.J. Bernet (1990), Monumental Bali. Singapore: Periplus.

Lansing, J. Stephen (1991), Priests and programmers: Technologies of power in the engineered landscape of Bali. Princeton, NJ.: Princeton University Press.

Lieberman, Victor (2003-2009), Strange parallels: Southeast Asia in global context, c. 8001830. Vol. 1-2. Cambridge: Cambridge University Press.

Lintgensz, Aernoudt (1856), "Bali 1597", Bijdragen tot de Taal-, Land- en Volkenkunde 5:202-32.

McWilliam, Andrew, David Bulbeck, Sally Brockwell and Sue O'Connor (2012), "The cultural legacy of Makassar stone in East Timor", The Asia Pacific Journal of Anthropology 13,3: 262-79.

Manca, Lalu (1984), Sumbawa pada masa lalu (Suatu tinjauan sejarah). Surabaya: Rinta.

Noorduyn, J. (1987), "Makasar and the Islamization of Bima", Bijdragen tot de Taal-, Landen Volkenkunde 143 2-3: 312-42.

Ptak, Roderich (1992), "The northern trade route to the spice islands: South China Sea - Sulu Zone - North Moluccas (14 ${ }^{\text {th }}$ to early $16^{\text {th }}$ century)", Archipel 43: 27-56.

Rappoport, Dana \& Dominique Guillaud (2015), "Reconsidérer 1'Est insulindien", Archipel 90: 27-56.

Reid, Anthony (1988-1993), Southeast Asia in the age of commerce 1450-1680. Vol. 1-2. New Haven: Yale University Press.

Rodemeier, Susanne (1995), "Local tradition on Alor and Pantar; An attempt at localizing Galiyao", Bijdragen tot de Taal-, Land-en Volkenkunde 151: 438-42.

Rodemeier, Susanne (2006), Tutu kadire in Pandai, Munaseli: Erzählen und Erinnern auf der vergessenen Insel Pantar (Ostindonesien). Berlin: LIT.

Roever, Arend de (2002), De jacht op sandelhout; De VOC en de tweedeling van Timor in de zeventiende eeuw. Zutphen: Walburg Pers.

Schrieke, B. (1955), Indonesian sociological studies, Vol. I. The Hague \& Bandung: Van Hoeve.

Schulte Nordholt, H.G. (1971), The political system of the Atoni of Timor. The Hague: M. Nijhoff.

Schulte Nordholt, Henk (1996), The spell of power: A history of Balinese politics. Leiden: KITLV Press.

Schulte Nordholt, Henk (2011), "Dams and dynasty, and the colonial transformation of Balinese irrigation management", Human Ecology 39: 21-7.

Sjamsuddin, Helius (2013), Memori Pulau Sumbawa: Tentang sejarah interaksi budaya \& perubahan social politik di Pulau Sumbawa. Yogyakarta: Ombak. 
Tambiah, Stanley Jeyaraja (2013), "The galactic polity of Southeast Asia", HAU: Journal of Ethnographic Theory 3,3: 503-34.

Tajib, H. Abdullah (1995), Sejarah Bima Dana Mbojo. Jakarta: Harapan Masa PGRI.

Tiele, P.A. (1877, 1879, 1880, 1880, 1881, 1882, 1884, 1886, 1887), "De Europeërs in den Maleischen archipel", Bijdragen tot de Taal-, Land-en Volkenkunde 25: 321-420, 26: 1-69, 27: 260-340, 28: 395-482, 29: 153-214, 30: 141-242, 32: 49-118, 35: 257-355, 36: 199-307.

Usfinit, Alexander Un (2008), Maubes Insana. Yogyakarta: Penerbit Kanisius.

Vickers, Adrian (1989), Bali: A paradise created. Ringwood: Penguin.

Vickers, Adrian (1990), "Bali's most illustrious kingdom", in Eric Oey (ed.), Bali, island of the gods. Singapore: Periplus. Pp. 166-70.

Wang Gungwu (2012), "A two-ocean Meditteranean”, in Geoff Wade and Li Tana (eds), Anthony Reid and the study of the Southeast Asian past. Singapore: ISEAS. pp. 69-84.

Warna, I Wayan, et al. (eds) (1986), Babad Dalem. Teks dan terjemahan. Denpasar: Dinas Pendidikan dan Kebudayaan Propinsi Daerah Tingkat I Bali.

Warnk, Holger (2010), "The coming of Islam and Moluccan-Malay culture to New Guinea, c. 1500-1929", Indonesia and the Malay World 38, 110: 109-34.

Wellen, Kathryn Anderson (2014), The open door: Early modern Wajorese statecraft and diaspora. DeKalb: Northern Illinois University Press.

Widjojo, Muridan (2009), The revolt of Prince Nuku: Cross-cultural alliance-making in Maluku, c.1780-1810. Leiden: Brill.

Wiener, Margaret J. (1995), Visible and invisible realms: Power, magic, and colonial conquest in Bali. Chicago \& London: Chicago University Press 